\title{
Bioactivity guided isolation of the antifungal components in sawdust extracts of Piptadeniatrum africanum, and Terminalia ivorensis.
}

\author{
Ogundare A. $0 .^{1 *}$ and Olajuyigbe A.O. ${ }^{2}$ \\ ${ }^{1}$ Department of Microbiology, Federal University of Technology, Akure. Ondo State, Nigeria. \\ ${ }^{2}$ Department of Biology, Adeyemi College of Education, Ondo, Nigeria. \\ E-mail:ayodeleogundare@yahoo.com
}

Received 10 May 2011; received in revised form 27 November 2011; accepted 25 December 2011

\begin{abstract}
Aim: The antifungal activities of extracts from fresh sawdust of Piptadeniatrum africanum,and Terminalia ivorensis was determined using the agar well diffusion method. Aqueous, methanol, chloroform,and $n$-hexane extracts obtained from the sawdust samples were tested against fungi isolated from some decayed wood samples. Methodology and Results: Fungal isolates included: Aspergillus niger, Aspergillus flavus, Aspergillus fumigates, Aspergillus wentii, Aspergillus tamari, and Penicillium chrysogenum. Results of inhibitory activities showed that the chloroform extracts showed the highest inhibitory abilities with zones of inhibition ranging from $14 \mathrm{~mm}-24 \mathrm{~mm}$ for $P$. africanum, and $11 \mathrm{~mm}-15 \mathrm{~mm}$ for $T$. ivorensis. However, the aqueous extracts exhibited the least antifungal activity with zones of inhibition ranging between $10 \mathrm{~mm}-13 \mathrm{~mm}$ and $8 \mathrm{~mm}-11 \mathrm{~mm}$ respectively. Conclusion, significance and impact of study: The major secondary plant metabolites identified are alkaloids, anthraquinones, anthraglycosides, arbutin, glycosides, flavonoids, phenolics, saponins, coumarins and valepotriates. The antifungal components in $P$. africanum were identified to be $3,7,8,3$,Tetramethoxy-6-C-methyl-5, 4'-dihydroxyflavone and 3-methoxy-6-C-methyl-3',4',5,7,8-pentahydroxyflavone while Terminalia ivorensis contained 5,7,8-Trihydroxy-2'5'-methoxy-3',4'-methylenedioxyisoflavanone as the bioactive component.
\end{abstract}

Keywords: antifungal, extracts, bioactive components, fungal isolates, wood, sawdust.

\section{INTRODUCTION}

Wood is a natural and renewable resource used extensively in the home, office, for furniture and construction of fences, utility poles, etc. Wood is one of the oldest and least costly of available construction materials. This renewable natural resource is used for a variety of purposes because of its unique combination of properties which include high strength-to-weight ratio, resiliency, and toughness (Bultman and Southwell, 1976). Throughout recorded history, the unique characteristics and relative abundance of wood have made it man's most valuable and useful natural resources. Today, literally thousands of available products from solid wood, wood pulp and chemicals are derived from wood (Hoadley, 1990).

Blanchete and Shaw (1978) explained that wood decay is deterioration of wood by primarily enzymatic activities of microorganisms and that fungi are the major agents causing wood decay. There are other kinds of deterioration though, caused by insects and marine animals, but this is not decay, nor is it quantitatively as important as decay. microbes act directly on individual components (such as cellulose and lignin) of the wood cell wall by the production of extracellular enzymes, such as cellulase and pectinase which destroy the wood components (Hoadley 1990 and Adeleye and Lashebikan, 2003).

In the natural forest, the tree grows, reaches full maturity, falls and is broken down by organisms. Humus and essential materials are returned to the forest soil, more trees grow and the cycle continues. Organisms have evolved depending heavily on wood as their main source of nutrition.

In wood decay, three classes of fungi are of prime importance:

(1) Basidiomycetes - Spores are borne on outside of a special organ called basidium. The basidiomycetes include the fungi giving rise to brown and white rots. They are capable of metabolising the lignin and carbohydrate components of wood (white rot) or primarily the carbohydrate component (brown rot) (Bultman and Southwell, 1976). The Basidiomycetes generally occur in moist and fairly well-aerated conditions.

(2) Ascomycetes - Spores borne inside a special structure - the Ascus. The Ascomycetes give rise to soft rot by the degrading the secondary layers of wood cellwalls and they can tolerate lower levels of aeration than Basidiomycetes.

(3) Fungi imperfecti also contain species capable of causing soft rot in wood. These fungi resemble Ascomycetes in many ways but differ from them by not undergoing a perfect spore bearing phase (Blanchette and Shaw, 1978)

\section{*Corresponding author}


Soft rot fungi, primarily ascomycetes and fungi imperfecti degrade secondary layers of wood cell walls. Under favourable conditions of temperature, air and moisture content of the wood, brown and white rot fung penetrate deeply into the wood, spreading from cell to cell and enzymatically degrading the cell wall components and storage products from which they obtain the nutrients and energy necessary for their survival. (Barry et al., 2002). The soft rot fungi attack the outer layers of wood cells and cause a gradual softening of wood from the surface inward as successive layers of cells are colonized and decayed (Bultman and Southwell, 1976).

It has been established that woods contain extractives known to confer protection against wooddecaying microorganisms (Dinwoodie, 1981; Barry et al., 2002). Plants have an almost limitless ability to synthesize aromatic substances, most of which are phenols or their oxygen-substituted derivatives (Iwu et al., 1999). Most are secondary metabolites in many cases. These substances serve as plant defense mechanisms against microorganisms, insects and herbivores (Cowan, 1999; Khan et al., 2002).

Many constituents of wood are toxic or inhibitory to fungi (Cobb et al., 1968). Of these, tannins and phenols have received most attention.In view of the continued problems and daily constraints on plant disease control methods and applications particularly those arising through the use of chemicals such as pesticides, insecticides and fungicides plant pathologist are increasing their efforts in developing areas for the achievement of successful biological control systems. In turn this has led to its recognition as a possible practical method for soil borne and aerial pathogens control (Madigan et al, 2000; Fatubarin, 2006).

\section{MATERIALS AND METHODS}

\section{Isolation of microorganisms}

The wood samples, were surface sterilized by flooding with $0.1 \% \mathrm{v} / \mathrm{v}$ solution of mercuric chloride (Adeleye and Omotosho, 2003). Isolation was by the method described by Levy and Dickinson (1981). A small cut made below the surface and a piece of underlying wood tissues (about $2 \mathrm{~g}$ ) was removed aseptically and placed in a sterile pestle and mortar. The wood sample was crushed and suspended in $9 \mathrm{~mL}$ of sterile distilled water. Serial dilution was carried. Exactly $1 \mathrm{ml}$ of the $10^{-6}$ diluted solution of each wood sample was inoculated on potato dextrose agar plates enriched with $0.1 \%$ sawdust. The plates were incubated at $30{ }^{\circ} \mathrm{C}$ for $48 \mathrm{~h}$ and later purified by subculturing onto fresh potato dextrose agar at ambient temperature for $48 \mathrm{~h}$.

\section{Identification of Fungal Isolates}

Isolated fungi were identified based on the observation of cultural and morphological characteristics, colour of colony and sporulation. Examination was carried out using needle-mount preparation whereby fragments of the sporing surface of the culture was taken. This was teased out in drop of alcohol on a cleaned glass slide using needle. The fragment was stained by adding a drop of lactophenol. A cover slip was applied carefully avoiding air bubbles and the preparation was examined under light microscope (Barnett and Hunter, 1972).Potato dextrose agar (PDA) and Czapek Dox agar (CDA) were used for cultivation of cultures (Haung and Ling, 1973 and Difco, 1984).

\section{Sawdust sample extraction}

Exactly $300 \mathrm{~g}$ each of the sawdust sample from the healthy woods of Piptadeniatrum africanum, and Terminalia ivorensis was soaked in $750 \mathrm{~mL}$ of methanol. The solution was left on the laboratory bench for $72 \mathrm{~h}$ after which it was filtered first with muslin cloth, then with No. 1 Whatman filter paper. The filtrate was dried using the rotary evaporator and the extract was obtained. Similar procedure was used to obtain chloroform and n-hexane extracts (Ogundare, 2005; Wang and Weller, 2006).

\section{Antifungal activities of the crude extract}

Each of the crude extracts were screened for antifungal activities against the fungal isolates implicated in wood decay using the agar-well diffusion method described by Olutiola and Akintunde (1991). Spores of the fungal isolates were introduced into sterile water; one $\mathrm{mL}$ of the stock was introduced into sterile Petri dish on to which sterile potato dextrose agar was poured. Using a $4 \mathrm{~mm}$ sterile cork borer, holes were made inside the agar, and into these holes solution of the crude extracts were introduced. The plates were incubated at room temperature $\left(28{ }^{\circ} \mathrm{C} \pm 2{ }^{\circ} \mathrm{C}\right)$ for $3-7$ days and they were examined for fungal growth. The antifungal activity of the extracts, as indicated by clear zones of growth inhibition around the wells, was examined and recorded in millimeters. Control experiment was carried out alongside introducing sterile water into the holes borne instead of the crude extract solution.

\section{Phytochemical Screening}

Basic phytochemical analysis was carried out to determine the bioactive ingredient present in the extracts. The conventional methods of Harbone (1984) and Wagner and Bladt (2001) were adopted.

\section{Fractionation of the extracts}

Exactly $3 \mathrm{~g}$ of the crude extracts that exhibited antifungal activity was each absorbed on silica gel of 60-120 mesh $(\mathrm{BDH})$ and chromatographed on a column of silica gel 60 slurry packed in petroleum ether. The column was gradient eluted first with petroleum ether and then with ethyl acetate: methanol $40: 1$ and finally with $100 \%$ methanol.

The fractions collected were analyzed by thin layer chromatography (TLC) on a precoated plates Merck silica 
gel 60 F254, $0.2 \mathrm{~mm}$ thickness using ethyl acetate : methanol (40:1), butanol : water (1:1), chloroform pyridine (1:1), methanol: ammonium hydroxide(200:3); acetate : pyridine : water $(5: 1: 4)$; chloroform : hexane : ethanol : acetic acid (5:4:1:1) as the mobile phases. Fractions showing the same TLC characteristic were bulked together and numbered. This was also confirmed by measuring their absorbance with the aid of spectrophotometer and later concentrated in vacuo. Visualization of the spots on plates was by observing under ultra violet light and by spraying separately with vanillin-sulphuric acid reagent followed by heating at $100^{\circ} \mathrm{C}$ for $5 \mathrm{~min}$.

Each of the numbered fractions was tested against each fungi implicated in wood decay. Fractions that gave antifungal activity were spotted on the thin layer chromatograph (TLC). The fractions were analysed by thin layer chromatography with the stationary phase on silica gel (60 $\mathrm{Fe}_{2} \mathrm{SO}_{4}, 0.2 \mathrm{~mm}$ thickness) and the mobile phase as n-hexane: chloroform: ethanol: acetic acid $(5: 2: 1: 1 \mathrm{v} / \mathrm{v})$. All the fractions that gave antifungal activities were subjected to IR, MS and NMR to obtain the structure of the active compounds. All the pure fractions from each of the extracts above were subjected to IR, MS and NMR to get the active compounds.

All the IR spectra were recorded with a Perkin Elmer (Precisely) Spectrum 100 series FT-IR spectrometer, while UV spectra were obtained from a Unicam UV 4-100 UV/Vis spectrophotometer. The MS were obtained using JEOL JMS-AX505HA double-focusing probe at $70 \mathrm{eV}$, while NMR spectra (both 1D and 2D) were obtained on a Bruker AMX- 400 (at $400 \mathrm{MHz}$ for ${ }^{1} \mathrm{H}$ NMR and $100 \mathrm{MHz}$ for ${ }^{13} \mathrm{C}$ NMR) spectrometer in $\mathrm{C}_{5} \mathrm{D}_{5} \mathrm{~N}$.

All data obtained were subjected to statistical analysis of variance (ANOVA) to determine the significance of the sources of variation while Duncan Multiple Range Test was used to determine the significant difference between the means at $5 \%$ level of significance ( $p \leq 0.05)$ (Duncan, 1995).

\section{RESULTS AND DISCUSSION}

The various fungi isolated from decayed wood samples included Aspergillus flavus, Aspergillus niger, Aspergillus fumigates, Aspergillus wentii, Aspergillus tamari, and Penicillium chrysogenum (Table 1). These fungi identified in decayed wood samples in this study, have been implicated in the deterioration of wood and wood products (Dickinson and Pugh, (1974); Levy and Dickinson, (1981); Adeleye and Omotosho, (2003). A. Flavus, A. tamarrii and A. fumigatus among other Aspergillus species have been implicated in various types of wood decomposition (Adeleye and Omotosho, 2003).

In general, the extracts from each of the solvents (methanol, chloroform, and $n$-hexane) exhibited zones of inhibition against the decay fungi (Table 2). Extracts from -hexane gave the highest antagonistic activities followed by chloroform, and methanol in that order.
Table 1: Cultural characterization and microscopic observation of the fungal isolates.

\begin{tabular}{|c|c|c|c|}
\hline $\mathrm{S} / \mathrm{N}$ & $\begin{array}{l}\text { Observation } \\
\text { On Potato } \\
\text { Dextrose } \\
\text { Agar }\end{array}$ & $\begin{array}{l}\text { Microscopic } \\
\text { observation }\end{array}$ & Isolates \\
\hline 1. & $\begin{array}{l}\text { Colonies } \\
\text { spreading } \\
\text { rapidly. } \\
\text { Yellowish at } \\
\text { first then } \\
\text { yellowish } \\
\text { green with } \\
\text { age. }\end{array}$ & $\begin{array}{l}\text { Vesicles small, } \\
\text { phialides entire } \\
\text { and conidia } \\
\text { globose and in } \\
\text { chains. Mycelium } \\
\text { branched and } \\
\text { septate. }\end{array}$ & $\begin{array}{l}\text { Aspergillus } \\
\text { flavus }\end{array}$ \\
\hline 2. & $\begin{array}{l}\text { Colonies } \\
\text { spread } \\
\text { rapidly with } \\
\text { mycelium } \\
\text { white at first } \\
\text { and bear } \\
\text { black heads } \\
\text { with age. }\end{array}$ & $\begin{array}{l}\text { Vesicles present. } \\
\text { Metullae and } \\
\text { phialides were } \\
\text { born on the } \\
\text { vesicle. Non- } \\
\text { septate and no } \\
\text { collumella. }\end{array}$ & $\begin{array}{l}\text { Aspergillus } \\
\text { niger }\end{array}$ \\
\hline 3. & $\begin{array}{l}\text { Colonies } \\
\text { spead rapidly } \\
\text { with } \\
\text { mycelium } \\
\text { dirty white } \\
\text { first then blue } \\
\text { with age }\end{array}$ & $\begin{array}{l}\text { Vesicles present. } \\
\text { Interwoven mass } \\
\text { of hyphae which } \\
\text { were septate. }\end{array}$ & $\begin{array}{l}\text { Aspergillus } \\
\text { fumigatus }\end{array}$ \\
\hline 4. & $\begin{array}{l}\text { Colonies } \\
\text { spread } \\
\text { rapidly. } \\
\text { Yellowish at } \\
\text { first then } \\
\text { turned } \\
\text { greenish with } \\
\text { age }\end{array}$ & $\begin{array}{l}\text { Vesicles present. } \\
\text { The mycelium } \\
\text { branched and } \\
\text { septate. }\end{array}$ & $\begin{array}{l}\text { Aspergillus } \\
\text { wentii }\end{array}$ \\
\hline 5. & $\begin{array}{l}\text { Colonies } \\
\text { spread } \\
\text { rapidly with } \\
\text { mycelium } \\
\text { whitish at first } \\
\text { and became } \\
\text { dark grey with } \\
\text { age }\end{array}$ & $\begin{array}{l}\text { Vesicle present. } \\
\text { Metulae and } \\
\text { phialide were born } \\
\text { on the vesicle. } \\
\text { Heads were } \\
\text { globose when } \\
\text { seen in petridish }\end{array}$ & $\begin{array}{l}\text { Aspergillus } \\
\text { tamari }\end{array}$ \\
\hline 6. & $\begin{array}{l}\text { Colonies } \\
\text { bluish-green } \\
\text { and velvety }\end{array}$ & $\begin{array}{l}\text { Brush } \\
\text { arrangements of } \\
\text { conidia and were } \\
\text { borne on } \\
\text { metullae. The } \\
\text { branching of the } \\
\text { spore-bearing } \\
\text { head was } \\
\text { monoverticillate }\end{array}$ & $\begin{array}{l}\text { Penicillium } \\
\text { chrysogenum }\end{array}$ \\
\hline
\end{tabular}


Table 2: Inhibitory effect of crude sawdust extracts (50 mg/mL of solvent) on fungi associated with wood decay.

\begin{tabular}{|c|c|c|c|c|c|c|c|}
\hline Sample & Solvent & $\begin{array}{l}\text { Aspergillus } \\
\text { niger }\end{array}$ & $\begin{array}{l}\text { Aspergillus } \\
\text { flavus }\end{array}$ & $\begin{array}{l}\text { Aspergillus } \\
\text { fumigatus }\end{array}$ & $\begin{array}{l}\text { Aspergillus } \\
\text { wentii }\end{array}$ & $\begin{array}{l}\text { Aspergillus } \\
\text { tamarii }\end{array}$ & $\begin{array}{l}\text { Penicillium } \\
\text { chrysogenum }\end{array}$ \\
\hline \multicolumn{8}{|c|}{$\begin{array}{l}\text { Piptandeniastrum } \\
\text { africanum }\end{array}$} \\
\hline & \multirow[t]{2}{*}{ methanol } & $12.50 \mathrm{c}$ & $15.17 \mathrm{c}$ & $12.83 \mathrm{c}$ & $14.67 \mathrm{c}$ & $11.50 \mathrm{c}$ & $13.50 \mathrm{c}$ \\
\hline & & \pm 0.29 & \pm 0.17 & \pm 0.17 & \pm 0.33 & \pm 0.29 & \pm 0.76 \\
\hline & \multirow[t]{2}{*}{ chloroform } & $14.00 \mathrm{~b}$ & $20.83 b$ & $16.33 b$ & $24.67 b$ & $15.67 b$ & $22.00 \mathrm{~b}$ \\
\hline & & \pm 0.00 & \pm 0.60 & \pm 0.33 & \pm 0.33 & \pm 0.33 & \pm 1.53 \\
\hline & \multirow[t]{2}{*}{ n-hexane } & $18.17 a$ & $25.67 a$ & $28.00 \mathrm{a}$ & $27.50 \mathrm{a}$ & $17.33 a$ & $26.67 a$ \\
\hline & & \pm 0.17 & \pm 0.33 & \pm 0.58 & \pm 0.29 & \pm 0.33 & \pm 0.67 \\
\hline \multicolumn{8}{|l|}{ Sterculia } \\
\hline rhinopetala & \multirow[t]{2}{*}{ methanol } & $12.00 \mathrm{c}$ & $12.33 \mathrm{c}$ & $10.00 \mathrm{c}$ & $13.00 \mathrm{c}$ & $10.00 \mathrm{~b}$ & $14.67 \mathrm{c}$ \\
\hline & & \pm 0.00 & \pm 0.17 & \pm 0.58 & \pm 0.00 & \pm 0.00 & \pm 0.33 \\
\hline & \multirow[t]{2}{*}{ chloroform } & $12.83 b$ & 18.33b & $14.33 b$ & $20.00 b$ & $15.33 a$ & $16.67 b$ \\
\hline & & \pm 0.17 & \pm 0.17 & \pm 0.67 & \pm 0.00 & \pm 0.33 & \pm 0.33 \\
\hline & \multirow[t]{2}{*}{ n-hexane } & 13.83a & $20.17 a$ & 21.33a & $21.67 a$ & $15.00 \mathrm{a}$ & $19.00 \mathrm{a}$ \\
\hline & & \pm 0.17 & \pm 0.17 & \pm 0.67 & \pm 0.33 & \pm 0.00 & \pm 0.58 \\
\hline
\end{tabular}

Values are mean of triplicate measurements.

Values along column with same superscripts are not significantly different $(p \geq 0.05)$.

$\pm=$ Standard errors of mean.

Table 3: Phytochemical screening of sawdust extracts of wood samples.

\begin{tabular}{|c|c|c|c|c|c|c|c|c|c|c|}
\hline \multirow[b]{2}{*}{ Wood samples } & \multicolumn{10}{|c|}{ Metabolites } \\
\hline & Solvents & Tann & Alkd & Antq & Glc & Flvd & Phnl & Spni & Cumr & VIpt \\
\hline \multirow[t]{2}{*}{ Sterculia rhinopetala } & $\mathrm{M}$ & + & + & + & + & + & - & + & + & - \\
\hline & $\mathrm{H}$ & + & + & + & + & + & + & + & + & - \\
\hline \multirow[t]{2}{*}{ Piptandeniastrum africanum } & M & + & + & + & + & + & + & + & + & + \\
\hline & C & + & + & + & + & + & + & + & + & + \\
\hline
\end{tabular}

Key (+) = Positive to test, Alkd: Alkaloids, Vlpt: Valepotriate, Antq: Anthraquinones, Glc: Glycosides, Tann: Tannins

$(-)=$ Negative to test, Phnl: Phenolics, Flvd: Flavonoids, Spni: Saponins, Cumr: Coumarins, H: n-Hexane, M: Methanol, C: Chloroform

Piptandeniastrum africanum's n-hexane extract gave highest zone of inhibition (28.00 mm) against Aspergillus wentii. Earlier workers (Shain, 1976; Cobb et. al., 1968; Ahmad et. al., 1998; Wang and Weller, 2006; Abhilash and Singh, 2008; Ahmad et al., 2009) hadhad reported $n$-hexane to be a good solvent for wood extractives.

Phytochemical screening of the crude extracts revealed the presence of constituents such as alkaloids, anthraquinones, glycosides, flavonoids, valepotriates, phenolics, saponins, and coumarins (Table 3). These extractable organic compounds naturally deposited in the heartwood during its transformation from sapwood generally are more important contributors to the natural resistance of wood to biodegradation than are inorganic constituents or physical factors such as wood density and degree of cellulose crystallinity (Bultman and Southwell, 1976; Ghoshal et al., 1996; Iwu et al., 1999). Terpenoids, essential oils and some flavonoid compounds were reported to exhibit antifungal activities on some brown and white rot fungi (Cobb et al., 1968; Carll and Highley, 1999).
Some of these compounds, such as saponin, were found to be fungistatic (Ahmad et al., 1998; Zehavi et al, 2008) while others, such as terpenoids, were found to be fungicidal (Fabry et al., 1996; Molina-Torres et al., 2004; Tripathi et al., 2008).

Phytochemical compounds reported in this research work have also been reported by Abiy et al. (2005) who detected flavonoids from Erythrina burttii as active against some microorganisms. Flavonoids and tannins have also been reported as responsible for the antimicrobial activities of forty-five medicinal plants (Ahmad and Berg, 2001). Moreover, it is reported that flavonoids are components synthesized by plants in response to microbial infection (Dixon et al., 1983) thus justifying their antagonistic activities in the test extracts.

Development of the fractions on thin layer chromatography (TLC) plates showed the presence of flavonoids, coumarins, anthraquinones, alkaloids, saponins and valepotriates. Anthraquinones were detected as a consistent bioactive component in all the wood species. Saponin was found in all the wood species. 
However, valeopotriates was detected only in $P$ africanum and found to be one of the active components in same. This compound may be responsible for its unusual resistance to wood decay by fungi.

The structure of the bioactive components in Sterculia rhinopetala (Aye) extract was elucidated and it gave a yellow waxy solid (C1). The structure was established by UV, IR, MS and a series of $1 D$ and 2D NMR analyses and suggested as 5,7,8-Trihydroxy-2'5'methoxy-3',4'-'methylenedioxyisoflavanone (Figure 1). C1 is a Yellow waxy solid, melting point $185-187^{\circ} \mathrm{C}$, with UV $\lambda_{\max } \mathrm{nm}(\log \varepsilon)$ : 214(4.10), 218 (4.12), 288 (4.00), 333 (sh) (3.25). IR $v_{\max } \mathrm{cm}^{-1}$ pronounced peaks at: 3421 , 2914, 1634, 1472, 1386, 1358, 1257, 1224, 1161, 1100, 1068, 925; the ${ }^{1} \mathrm{H}$ NMR, (Figure 2), ${ }^{13} \mathrm{C}$ NMR (Figure 3) and heteronuclear multiple bond correlation (HMBC) is as shown in Tables 4 and 5. Electron Impact Mass Spectrum (EIMS) molecular ion peak $(\mathrm{M})^{+\cdot} \mathrm{m} / z 378.0625$ (calculated for $\mathrm{C}_{18} \mathrm{H}_{18} \mathrm{O}_{9}, 378.0623$ ), 5,7,8-Trihydroxy-2',5'-dimethoxy3',4'-methylenedioxyisoflavanone (Figure 3 ).

Table 4: ${ }^{1} \mathrm{H}$ NMR $(400 \mathrm{MHz})$ data of $\mathrm{C} 1$ and ${ }^{13} \mathrm{C}$ NMR $(100 \mathrm{MHz})$ data of $\mathrm{C} 1$ in $\mathrm{C}_{5} \mathrm{D}_{5} \mathrm{~N}$

\begin{tabular}{|c|c|c|}
\hline Position & ${ }^{1} \mathrm{H}$ & ${ }^{13} \mathrm{C}$ \\
\hline \multirow[t]{2}{*}{2} & $4.69, t, J=11.0 \mathrm{~Hz}$ & 71.1 \\
\hline & $4.50, d d, J=10.5,5.6 \mathrm{~Hz}$ & - \\
\hline 3 & $4.43, d d, J=11.0,5.6 \mathrm{~Hz}$ & 48.5 \\
\hline 4 & - & 197.6 \\
\hline 5 & - & 166.0 \\
\hline 6 & $6.52, d, J=2.0 \mathrm{~Hz}$ & 97.7 \\
\hline 7 & - & 168.6 \\
\hline 8 & - & 96.5 \\
\hline 9 & - & 164.7 \\
\hline 10 & - & 103.3 \\
\hline $1^{\prime}$ & - & 121.4 \\
\hline $2^{\prime}$ & - & 142.5 \\
\hline $3^{\prime}$ & - & 137.8 \\
\hline $4^{\prime}$ & - & 149.8 \\
\hline $5^{\prime}$ & - & 145.6 \\
\hline $6^{\prime}$ & $6.80, d, J=8.3 \mathrm{~Hz}$ & 125.1 \\
\hline $5-\mathrm{OH}$ & 12.89, br. s & - \\
\hline $7-\mathrm{OH}$ & 12.98, br. $s$ & - \\
\hline $8-\mathrm{OH}$ & 13.02, br. $s$ & - \\
\hline 2'-OMe & $3.96, s$ & 59.6 \\
\hline 5'-OMe & $3.87, \mathrm{~s}$ & 60.2 \\
\hline$-\mathrm{OCH}_{2} \mathrm{O}-$ & $5.90, s$ & 102.0 \\
\hline
\end{tabular}

For Piptandeniastrum africanum extract, the bioactive component also gave a yellow amorphous powder melting point (m.p.) $234-236{ }^{\circ} \mathrm{C}$ (C2) and a yellow fluffy powder m.p. $217-219^{\circ} \mathrm{C}(\mathbf{C} 3)$. The $\mathrm{C} 2$ properties were observed as $\mathrm{V} \lambda_{\max } \mathrm{nm}(\log \varepsilon)$ : 255 (4.64), 357 (4.62); +NaOAc: 271 , 365; +NaOH: 276, 343, and 410. ${ }^{+} \mathrm{AICl}_{3}: 279$, 440. IR (v $\mathrm{cm}^{-1}$ ) pronounced peaks: $3401,2932,1653,1612$, and 1556 EIMS: molecular ion peak $(\mathrm{M})^{+} \mathrm{m} / \mathrm{z} 388.0103$. (calculated molecular formula $\mathrm{C}_{20} \mathrm{H}_{20} \mathrm{O}_{8}$ ).
Table 5: HMBC data (400 MHz, $\left.\mathrm{C}_{5} \mathrm{D}_{5} \mathrm{~N}\right)$ of $\mathrm{C1}$

$\mathrm{J}=$ Coupling constants i.e. difference in chemical shifts in ppm.

\begin{tabular}{lll}
\hline \multirow{2}{*}{ Protons } & \multicolumn{2}{c}{$\mathrm{C} 1(\mathrm{H} \rightarrow \mathrm{C})$} \\
\cline { 2 - 3 } & $\mathrm{J}_{2}$ & $\mathrm{~J}_{3}$ \\
$\mathrm{H}-2$ & $\mathrm{C}-3$ & $\mathrm{C}-9, \mathrm{C}-4, \mathrm{C}-1^{\prime}$ \\
$\mathrm{H}-3$ & $\mathrm{C}-2, \mathrm{C}-4, \mathrm{C}-1^{\prime}$ & $\mathrm{C}-2^{\prime}, \mathrm{C}-6^{\prime}$ \\
$\mathrm{H}-6$ & $\mathrm{C}-5, \mathrm{C}-7$ & $\mathrm{C}-10, \mathrm{C}-8$ \\
$\mathrm{H}-6^{\prime}$ & $\mathrm{C}-5^{\prime}$ & $\mathrm{C}-3, \mathrm{C}-2^{\prime}, \mathrm{C}-4^{\prime}$ \\
$\mathrm{HO}-5$ & $\mathrm{C}-5$ & $\mathrm{C}-6, \mathrm{C}-10$ \\
$\mathrm{HO}-8$ & $\mathrm{C}-8$ & $\mathrm{C}-7, \mathrm{C}-9$ \\
$\mathrm{MeO}-2^{\prime}$ & - & $\mathrm{C}-2^{\prime}$ \\
$\mathrm{MeO}^{\prime} 5^{\prime}$ & - & $\mathrm{C}-5^{\prime}$ \\
$-\mathrm{OCH}_{2} \mathrm{O}-$ & - & $\mathrm{C}-3^{\prime}, \mathrm{C}-4^{\prime}$ \\
\hline
\end{tabular}<smiles>COc1cc([C@H]2COc3c(O)c(O)cc(O)c3C2=O)c(OC)c2c1OCO2</smiles>

Figure 1 : (C1) 5,7,8-Trihydroxy-2'5'-methoxy-3',4'methylenedioxyisoflavanone.

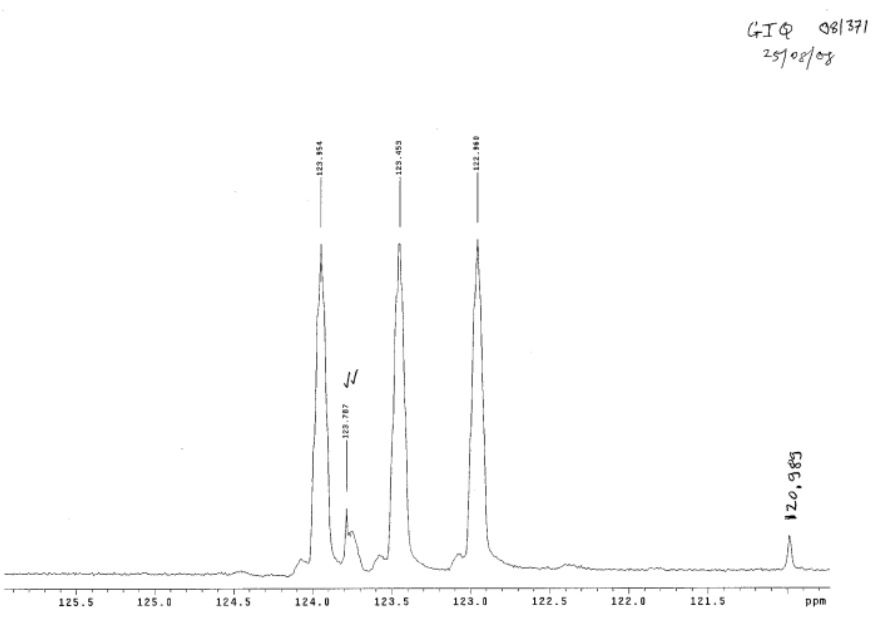

Figure 2: ${ }^{1} \mathrm{H}$ NMR for $\mathrm{C} 1$. 
Mal. J. Microbiol. Vol 8(1) 2012, pp. 34-41

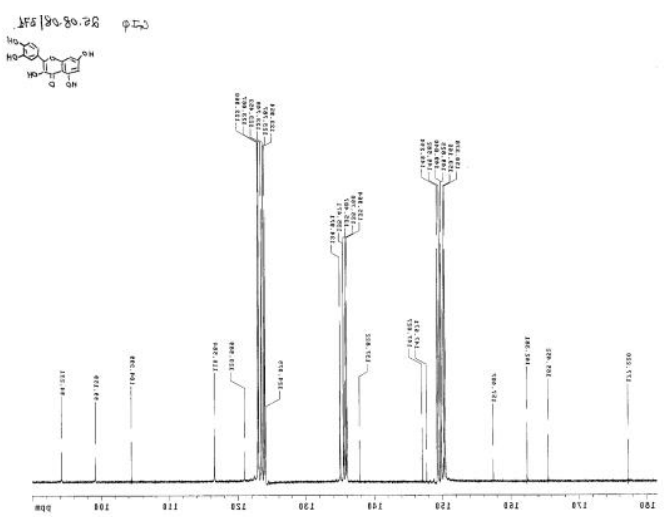

Figure $3:{ }^{13} \mathrm{C}$ NMR for $\mathrm{C} 1$.

${ }^{1} \mathrm{H}$ NMR: $\delta 2.14$ (3H, s, Me-6), 3.74 (3H, s, OMe-3), 3.96 (3H, s, OMe-3'), 4.01 (3H, s, OMe-7); 4.56 (3H, s, OMe-8), $6.91\left(1 \mathrm{H}, \mathrm{d}, \mathrm{J}=8.5 \mathrm{~Hz}, \mathrm{H}-5^{\prime}\right), 7.60(1 \mathrm{H}, d d, \mathrm{~J}=2.3,8.4 \mathrm{~Hz}$, $\left.\mathrm{H}-6^{\prime}\right), 7.70\left(1 \mathrm{H}, \mathrm{d}, \mathrm{J}=2.3 \mathrm{~Hz}, \mathrm{H}-2^{\prime}\right), 10.90\left(1 \mathrm{H}, \mathrm{s}, 4^{\prime}-\mathrm{OH}\right)$, $12.92(1 \mathrm{H}, \mathrm{s}, 5-\mathrm{OH}) .{ }^{13} \mathrm{C}$ NMR (Figures 4 and 5; Table 6$)$. The C2 compound was suggested to be $3,7,8,3^{\prime}-$ Tetramethoxy-6-C-methyl-5,4'-dihydroxyflavone(6-Cmethylquercetin 3, 3', 7, 8 - tetramethyl ether) (Figure 6).

The spectra properties for C3 were UV $\lambda_{\max } \mathrm{nm}$ (log ع): 260 (4.62), 351 (4.60); +NaOAc: 260, 355; +NaOH:

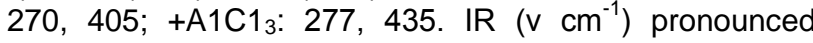
peaks: $3429,1652,1613,1568,1556$ EIMS: molecular ion peak $(\mathrm{M})^{+} \mathrm{m}^{+} \mathrm{z}$ 346.0752. (calculated mol. formula $\left.\mathrm{C}_{17} \mathrm{H}_{14} \mathrm{O}_{8}\right) .{ }^{1} \mathrm{H}$ NMR: $\delta 2.11(3 \mathrm{H}, \mathrm{s}, \mathrm{Me}-6), 3.87(3 \mathrm{H}, \mathrm{s}$, OMe-3), $7.03\left(1 \mathrm{H}, \mathrm{d}, \mathrm{J}=8.6 \mathrm{~Hz}, \mathrm{H}-5^{\prime}\right), 7.62(1 \mathrm{H}, \mathrm{dd}, \mathrm{J}=2.3$, $\left.8.6 \mathrm{~Hz}, \mathrm{H}-6^{\prime}\right), 7.75\left(1 \mathrm{H}, \mathrm{d}, \mathrm{J}=2.3 \mathrm{~Hz}, \mathrm{H}-2^{\prime}\right), 10.23(1 \mathrm{H}, \mathrm{s}$, $\left.4^{\prime}-\mathrm{OH}\right), 11.15\left(1 \mathrm{H}, \mathrm{s}, 3^{\prime}-\mathrm{OH}\right) .12 .05(1 \mathrm{H}, \mathrm{s}, 8-\mathrm{OH}), 12.90$ $(1 \mathrm{H}, \mathrm{s}, 7-\mathrm{OH}), 13.05(1 \mathrm{H}, \mathrm{s}, 5-\mathrm{OH}) .{ }^{13} \mathrm{C}$ NMR (Table 6 ; Figures 7 and 8). The molecular formula of $\mathrm{C} 3$ was assigned as $\mathrm{C}_{17} \mathrm{H}_{14} \mathrm{O}_{6}$ on the basis of the molecular ion peak at $\mathrm{m} / \mathrm{z} 346.0752$. C3 was consequently assigned the structure3-methoxy-6-C-methyl-3',4',5,7,8 pentahydroxyflavone (6-C-methylquercetin-3methylquercetin- 3 - methyl ether) (Figure 6).

GIQ 081371

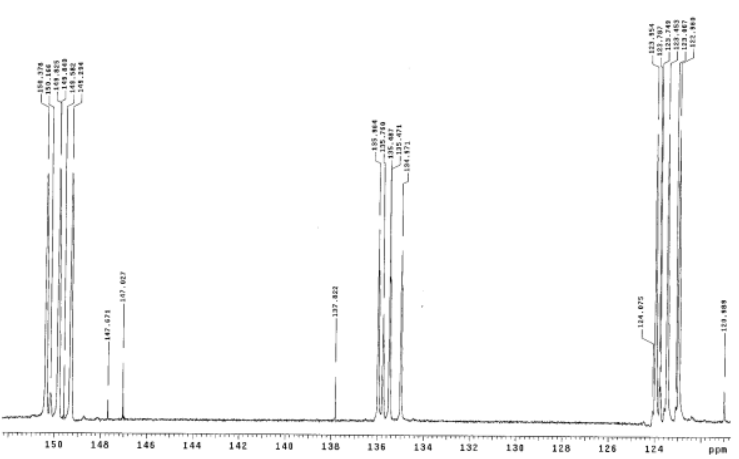

Figure 4: ${ }^{13} \mathrm{C}$ NMR for $\mathrm{C} 2$.

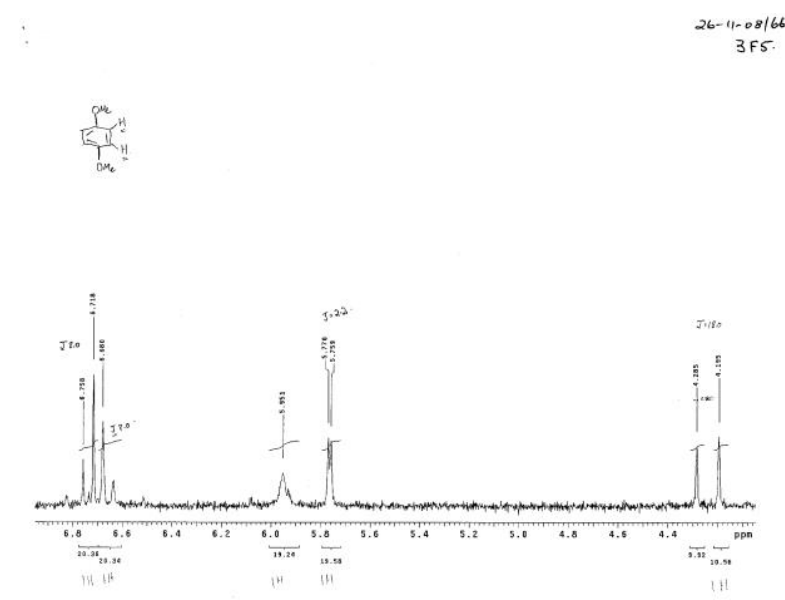

Figure 5: ${ }^{1} \mathrm{H}$ NMR for $\mathrm{C} 2$.<smiles>[R6]Oc1c(C)c(O)c2c(=O)c(OC)c(-c3ccc(O)c([R3])c3)oc2c1[R]</smiles>

Figure 6: Compound C2 - 3, 7, 8, 3'-Tetramethoxy-6-Cmethyl-5, 4'-dihydroxyflavone (6-C-methylquercetin 3, 3', 7, 8 - tetramethyl ether):

C3 - 3-methoxy-6-C-methyl-3',4',5,7,8-

pentahydroxyflavone (6-C- methylquercetin- 3 methylquercetin- 3 - methyl ether).

$\begin{array}{llll} & \mathrm{R}_{1} & \mathrm{R}_{2} & \mathrm{R}_{3} \\ \text { C2 } & \mathrm{OCH}_{3} & \mathrm{OCH}_{3} & \mathrm{OCH} \\ \text { C3 } & \mathrm{OH} & \mathrm{OH} & \mathrm{OH}\end{array}$

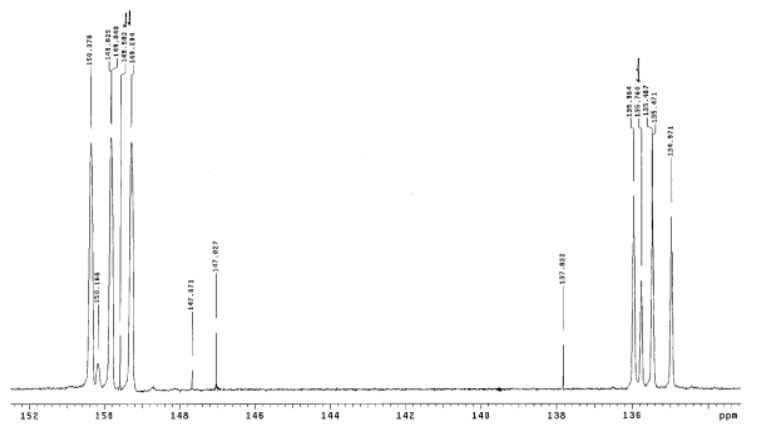

Figure 7: ${ }^{13} \mathrm{C}$ NMR for $\mathrm{C} 3$. 
Table 6: ${ }^{13} \mathrm{C}$ NMR $(100 \mathrm{MHz})$ data for compounds $\mathrm{C} 2$ and $\mathrm{C} 3$ in $\mathrm{C}_{5} \mathrm{D}_{5} \mathrm{~N}$.

\begin{tabular}{lll}
\hline Position & \multicolumn{2}{c}{${ }^{13}$ C NMR } \\
\cline { 2 - 3 } 2 & C2 & C3 \\
\cline { 2 - 3 } 3 & 155.5 & 155.0 \\
4 & 137.5 & 137.3 \\
5 & 178.8 & 177.9 \\
6 & 156.3 & 157.1 \\
7 & 106.6 & 107.3 \\
8 & 145.4 & 159.2 \\
9 & 149.5 & 162.8 \\
10 & 151.4 & 154.4 \\
$1^{\prime}$ & 103.9 & 104.8 \\
$2^{\prime}$ & 121.6 & 120.4 \\
$3^{\prime}$ & 115.3 & 115.4 \\
$4^{\prime}$ & 147.2 & 163.6 \\
5' & 148.5 & 164.5 \\
6' & 115.8 & 115.4 \\
3-OMe & 120.6 & 120.8 \\
7-OMe & 59.5 & 59.2 \\
8-OMe & 60.2 & - \\
3'-OMe & 63.5 & - \\
6-Me & 56.5 & - \\
\hline
\end{tabular}

$26-11-081662$
$3 F 5$

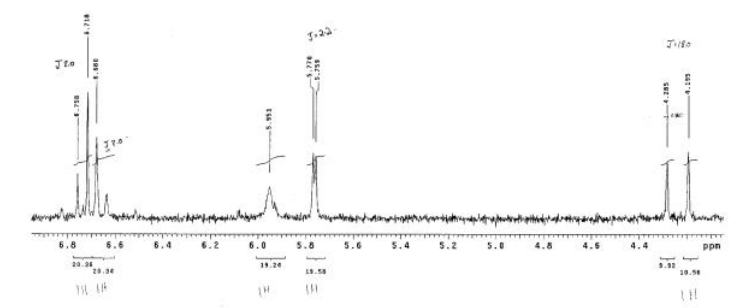

Figure 8: ${ }^{1} \mathrm{H}$ NMR for C3.

The extractable organic compounds naturally deposited in the heartwood are more important contributors to the natural resistance of wood to biodegradation (Carey et al., 1984; Martinez-Inigo et al., 2005). The major wood preservatives used today are water-borne chromated copper arsenate (CCA). However, there are some concerns with CCA including a public perception of possible arsenic exposure, leaching of the metal oxide and the question of the ultimate disposal of CCA-treated wood. Consequently, the use of biocontrol of wood decay which is more environmentally friendly and will make treated wood less expensive is a better alternative to chemical preservatives.

\section{ACKNOWLEDGMENT}

We hereby acknowledge the assistance rendered by Dr. Babajide of the Department of Chemistry, Adeyemi College of Education, Ondo, Nigeria, in whose laboratory we conducted the chemistry aspect of this work and who also helped us to interpret the spectra.

\section{REFERENCES}

Abiy, Y., Solomon, D., Jacob, O. M., Christine, C. B., Matthias, H., and Martin. G. P. (2005). Antimicrobial Flavonoids from the stem and bark of Erythrina burttii. Fitoterapia 96, 472-496.

Abhilash, P. C. and Singh, N. (2008). Multiple Residue Extraction for Organochlorine Pesticides in Medicinal Plants. Bulletin of Environmental Contamination and Toxicology 81(6), 604-607.

Adeleye L. A. and Lashebikan. O. M. (2003). Pectinase production by wood degrading fungi isolated from some Nigerian woods. Science Focus 5, 12-14.

Adeleye, L. A. and Omotosho, G. D. (2003). Isolation and characterization of wood degrading bacteria and fungi in Lagos, Nigeria. Science Focus 5, 113-115.

Ahmad, I. and Berg, A. Z. (2001). Antimicrobial and phytochemical studies on 45 Indian medicinal plants against multi-drug resistant human pathogens. Journal of Ethnopharmacology 74(1), 13-123.

Ahmad, I., Mahmood, Z. and Mohammed, F. (1998). Screening of some Indian medicinal plants for their antimicrobial properties. Journal of Ethnopharmacology 62, 183-193.

Ahmad, A., Alkarkhi, A. F. M., Hena, S. and Khim, L. H. (2009). Extraction, Separation and Identification of Chemical Ingredients Of Elephantopus Scaber $L$. Using Factorial Design of Experiment. International Journal of Chemistry 1(1), 36-49.

Barnett, H. L. and Hunter, B. B. (1972). Illustrated Genera of imperfect fungi $3^{\text {rd }}$ ed; Minnesota, Burgess publishing company, Minneapolis pp 241.

Barry, K. M., Davies, N. W. and Mohammed, C. L. (2002). Effect of season and different fungi on Phenolics in response to xylem wounding and inoculation in Eucalypus nitens. For. Path. 32(1).

Blanchette, R. A and Shaw, C. G. (1978). Associations among bacteria, yeasts and Basidiomycetes during wood decay. Phytophathology 68, 631-637.

Bultman, J. D. and Southwell, C. R. (1976). Natural Resistance of Tropical American Woods to Terrestrial wood-destroying organisms. Biotropical 8(2), 71-95.

Carey, J. K., Savory, J. G., Mendes, F. and Bravery, A. F. (1984). Loss of resistance to decay of scots pine heartwood in a biologically active environment. Applied Biochemistry and Biotechnology 9(4), 343344.

Carll, C. G. and Highley, T. L. (1999). Decay of wood and wood-based products above ground in buildings. Journal of Testing and Evaluation 27 (2), 150-158.

Cobb, F. W. Jr., Krstic, M., Zavarin, E. and Barber, H. W. Jr. (1968). Inhibitroy effects of volatile Oloresin 
components on Fomes annosus and four Ceratocystic species. Phytopathology 58, 1199-1324.

Cowan, M. M. (1999). Plant materials as antimicrobial agents. Clinical medical review 12 (4), 564-582.

Dickinson, C. H. and Pugh, G. J. F. (1974). Decomposition of wood. Biology of plant litter Decomposition. Academic Press Inc., London 1, pp. $129-169$.

Dinwoodie, J. M. (1981). Timber, its nature and behaviour. 1st Ed. Van Nostrand and Reinhold company, New York pp. 114-136.

Dixon, R. A., Dey, P. and Lamb, C. J. (1983). Phytoalexins: Enzymology and molecular biology. Advances in Enzymology. 55, 1-69.

Duncan, D. B. (1995). Multiple range and multiple F-tests. In Biometric II. McGraw-Hill, New York pp 1-42.

Fabry, W., Okemo, P., Ansorg, R. (1996). Fungistatic and fungicidal activity of east African medicinal plants. Mycoses. 39 (1-2), 67-70.

Fatubarin, A. (2006). Plant Pathology. Keynotes, llesa Nigeria. pp 66.

Ghoshal, S., Krishna, P., Prasad, B. N. and Lakshmi, V. (1996). Antiamoebic activity of Piper longum fruits against Entamoeba histolytica in vitro and in vivo. Journal of Ethnopharmacology 50, 167-170.

Harbone, J. B. (1984). Phytochemical methods. A guide to modern techniques of plant analysis. $2^{\text {nd }}$ edn. Chapman and Hall, New York pp. 1-35.

Hoadley R. B. (1990). Identifying wood. The Tanton press. New York pp. 55-86.

Iwu, M. W., Dunncan, A. R. and Okunji, C.O. (1999). New antimicrobials of plant origin. In: Perspectives on new crops and new uses. J. Janick (ed.). ASHS Press, Alexandria, V.A. pp. 457-462.

Khan, M. R., Khara, M. and Omotoso, A. D. (2002). Antimicrobial activity of Cassia alata. Fitoterapia 72 (5), 561-564.

Levy, J. F. and Dickson, D. J. (1981). Biodegradation of wood. Biodeterioration. Academic Press Inc. London. 6, pp. 1-551.

Madigan, M. T., Martinko, J. M. and Parkeer, J. (2000). Biology of Microorganisms. 9th Edition prentice Hall, Inc. Upper Saddle River, New Jerey. pp 991.

Martinez-Inigo, M. J., Immerzeel, P., Gutierrez, A., del Rio, J. C. and Sierra-Alvarez, R. (2005). Biodegradability of extractives in sapwood and heartwood from Scots Pine by sapstain and white-rot fungi. Holzforschung 53 (3), 247-252.

Molina-Torres, J., Salazar-Cabrera, C., ArmentaSalinas, C. and Ramírez-Chávez, E. (2004). Fungistatic and Bacteriostatic Activities of Alkamides from Heliopsis longipes Roots: Affinin and Reduced Amides. Journal of Agriculture and Food Chemistry 52 (15), 4700-4704

Ogundare, A. O. (2005). Phytochemical and Antimicrobial Properties of vernonia amygdalina Del and Vernonia tenoreana sensu Eyles. Ph.D. Thesis. Department of Microbiology, Federal University of Technology, Akure, Nigeria.
Olutiola, P. O. and Akintunde, A. (1991). Pectin lyase and pectin. Methyl esterase production by $P$. citrium. Transactions British Mycological Society 72, 49-55.

Shain, L. (1976). Resistance of sapwood in stems of laboratory pine to infection by Fomes annosus. Phytopathology 57, 1034-1045.

Tripathi, N. N., Asthana, A. and Dixit, S. N. (2008). Toxicity of some terpenoids against fungi infesting fruits and seeds of Capsicum annuum L. during storage. Journal of Phytopathology 110 (4), 328-335.

Wagner, H. and Bladt S. (2001). Plant drug analysis: A thin layer chromatography atlas. $2^{\text {nd }}$ edn, Springer, New York. pp. 349-364.

Wang, L. and Weller, C. L. (2006). Recent advances in extraction of nutraceuticals from plants. Trends in Food Science and Technology 17 (6), 300-312.

Zehavi, U., Levi, M. and Segal, R. (2008). Fungistatic Activity of Saponin A from Styrax officinalis L. on Plant Pathogens. Journal of Phytopathology 116 (4), 338-343. 